\title{
The state of vascular endothelium, clinical and metabolic features of patients with coronary heart disease combined with nonalcoholic fatty liver disease
}

\author{
N. S. Mykhailovska, L. Ye. Miniailenko \\ Zaporizhzhia State Medical University, Ukraine
}

Key words: coronary artery disease nonalcoholic

fatty liver disease, vascular endothelium, carotid intimamedia thickness, arginine.

Pathologia 2017; 14 (1), 62-67

Dol:

10.14739/2310-1237 2017.1.97505

E-mail: luba89@gmail.com
Objective: to study changes in the vascular endothelium state in conjunction with clinical and metabolic features in CHD patients with the concomitant nonalcoholic fatty liver disease.

Methods: cross-cohort analytical study involved 86 patients, the primarily selected group consisted of 34 patients, mean age $60(57.5 ; 66)$ with documented coronary artery disease, stable exertional angina of II-III functional class combined with NAFLD; comparison selected group: 32 patients, mean age $60.5(51.5 ; 65.6)$ with coronary artery disease without NAFLD. The control selected group consisted of 20 healthy individuals.

Results: In patients with coronary artery disease and NAFLD compared with CHD patients without NAFLD was found significantly higher levels of ADMA by $21 \%(p<0.05)$, CRP by 1.63 times $(p<0.05)$, intima-media thickness by $14.28 \%(p<0.05)$. Using ROC-analysis established that levels of ADMA $>0.74 \mathrm{mmol} / \mathrm{l}$ is the cutting point and has an optimal ratio of sensitivity $(80 \%)$ to the specificity $(82.9 \%$ ) for the diagnosis of vascular remodeling in CHD patients with concomitant NAFLD. The presence of significant direct correlation relationship of ADMA with CRP, total cholesterol, glucose, body mass index, alkaline phosphatase, ALT and significant negative relation of ADMA with HDL were found.

Conclusions: In patients with coronary artery disease, combined with NAFLD structural and functional changes in vascular endothelium (increase in serum levels of ADMA, thickening of intima-media) are observed during activation of systemic inflammation (increased CRP concentration), which is associated with metabolic disorders and liver damage indicators. The value of ADMA in serum prevailing $0.74 \mathrm{mmol} / /$ helps to diagnose structural and functional changes in vascular endothelium in patients with coronary artery disease, comorbid with NAFLD.
Кнючові слова:

ішемічна

хвороба серця,

неалкогольна

жирова хвороба

печінки,

ендотелій судин,

товщина комплексу

інтима-медіа,

аргінін.

Патологія. - 2017. -

T. 14, № 1(39). -

C. $62-67$

\section{Стан судинного ендотелію та кмініко-метаболічні особливості хворих на ішемічну хворобу серця, що поєАнана з неалкогольною жировою хворобою печінки}

\section{Н. С. Михайловська, ^. Є. Міняйленко}

Мета роботи - вивчити зміни стану судинного ендотелію у взаємозв'язку з клініко-метаболічними особливостями у хворих на ішемічну хворобу серця (IXC) із супутньою неалкогольною жировою хворобою печінки (НАЖХП).

Матеріали та методи. До поперечного когортного аналітичного дослідження в паралельних групах залучили 86 пацієнтів: основна група - 34 хворі з IXC: стабільною стенокардією напруження II-III функціонального класу в поєднанні з НАЖХП, медіана віку - $60(57,5 ; 66)$; група порівняння - 32 хворі з ІХC без НАЖХП, медіана віку - $60,5(51,5 ; 65,6)$. Усім хворим здійснили комплексне обстеження згідно із загальноприйнятими стандартами (наказ МОЗ України № 436 від 03.07.2006). За допомогою стандартних наборів реактивів імуноферментним методом визначали рівень інсуліну (Monobind, USA), асиметричного диметіларгініну ADMA (Immundiagnostik, Germany). Усім пацієнтам визначали товщину комплексу інтима-медіа ендотелію судин на апараті eSaote Mylab40 (Італія).

Результати. Визначили, що в пацієнтів з IXC і НАЖХП порівняно з хворими на IXC без НАЖХП вірогідно більші рівні ADMA на $21 \%$ ( $p<0,05)$, СРБ у 1,63 раза ( $<<0,05)$, товщина комплексу інтима-медіа на $14,28 \%(p<0,05)$. За допомогою $\mathrm{ROC}$-аналізу встановили, що рівень ADMA >0,74 ммоль/л $€$ точкою відсікання та має оптимальне співвідношення чутливості (80 \%) до специфічності (82,9 \%) щодо діагностики ремоделювання судин у хворих на ІХС із супутньою НАЖХП. 3'ясовано наявність вірогідного прямого кореляційного взаємозв'язку рівня ADMА з СРБ, рівнем загального холестерину, глюкози, індексом маси тіла, лужної фосффатази, АЛТ і вірогідного від'ємного зв'язку ADMA з ЛПВЩ.

Висновки. У хворих на IXC, що поєднана з НАЖХП, спостерігаються структурно-срункціональні зміни судинного ендотелію (збільшення сироваткового рівня ADMA, потовщення комплексу інтима-медіа) на тлі активації системного запалення (збільшення концентрації СРБ), які асоціюються з метаболічними порушеннями та індикаторами ураження печінки. Значення рівня ADMA в сироватці крові, що переважає 0,74 ммоль/л, дає змогу діагностувати структурно-функціональні зміни судинного ендотелію у хворих на IXC, коморбідну з НАЖХП.
Ключевые слова: ишемическая болезнь сераца, неалкогольная жировая болезнь печени, эндотелий СосуАОв, толщина комплекса интима-медиа, аргинин.

\section{Состояние сосудистого эндотелия и киинико-метаболические особенности больных ИБС в сочетании с неалкогольной жировой болезнью печени}

\section{Н. С. Михайловская, А. Е. Миняйленко}

Цель работы - изучить изменения состояния сосудистого эндотелия во взаимосвязи с клинико-метаболическими особенностями у больных ИБС с сопутствующей неалкогольной жировой болезнью печени.

Материалы и методы. Кпоперечному когортному аналитическому исследованию в параллельных группах привлечено 86 пациентов: основная группа - 34 больных с ИБС: стабильной стенокардией напряжения II-III функционального класса 
в сочетании с НАЖБП, медиана возраста - 60 (57,5; 66); группа сравнения - 32 больных с ИБС без НАЖБП, медиана возраста - 60,5 (51,5; 65,6). Всем больным проводили комплексное обследование в соответствии с общепринятыми стандартами (приказ М3 Украины № 436 от 03.07.2006). С помощью стандартных наборов реактивов иммуноферментным методом определяли уровень инсулина (Monobind, USA), асимметричного диметиларгинина ADMA (Immundiagnostik, Germany). Всем пациентам определяли толщину комплекса интима-медиа эндотелия сосудов на аппарате eSaote Mylab40 (Италия).

Результаты. Определено, что у пациентов с ИБС и НАЖБП в сравнении с больными ИБС без НАЖБП достоверно больше уровни ADMA - на $21 \%$ ( $2<0,05)$, СРБ - в 1,63 раза ( $p<0,05)$, толщина комплекса интима-медиа - на 14,28 \% $(\mathrm{p}<0,05)$. C помощью ROC-анализа установлено, что уровень ADMA >0,74 ммоль/л является точкой отсечения и имеет оптимальное соотношение чувствительности $(80 \%)$ к специфичности $(82,9 \%)$ относительно диагностики ремоделирования сосудов у больных ИБС с сопутствующей НАЖБП. Выяснено наличие достоверной прямой корреляционной взаимосвязи уровня ADMA с СРБ, уровнем общего холестерина, глюкозы, щелочной фоссратазы, АЛТ, индексом массы тела и достоверной обратной связи ADMA с ЛПВП.

Выводы. У больных ИБС, коморбидной с НАЖБП, наблюдаются структурно-функциональные изменения сосудистого эндотелия (увеличение сывороточного уровня ADMA, утолщение комплекса интима-медиа) на фоне активации системного воспаления (повышение концентрации СРБ), которые ассоциируются с метаболическими нарушениями и индикаторами поражения печени. Значение уровня ADMA в сыворотке крови, превышающее 0,74 ммоль/л, позволяет диагностировать структурно-функциональные изменения сосудистого эндотелия у больных ИБС, коморбидной с НАЖБП.

\section{Introduction}

Coronary heart disease (CHD) continues to gain the leading place in the structure of incidence and is one of the prevailing causes of death and disability in the population [1]. Metabolic disorders (diabetes, hypertension, dyslipidemia, obesity) 2-4 times raise the risk of coronary heart disease. Nonalcoholic fatty liver disease (NAFLD) is regarded to be one of the conditions associated with metabolic syndrome causing the deterioration of the quality of life, morbidity, and mortality. The prevalence of NAFLD in western countries is $20-30 \%, 2-3 \%$ of which have a progressive course with transformation into nonalcoholic steatohepatitis (NASH), cirrhosis, hepatocellular, carcinoma [2].

The leading link in the development of NAFLD is insulin resistance syndrome, characterized by the reduced tissues receptors sensitivity to insulin, resulting in increased synthesis of free fatty acids accumulated in the liver. The free fatty acids, in their turn, break the endothelial function through the following mechanisms: production of free radicals, activation of systemic inflammation, adipocytokine imbalance and dyslipidemia [3].

The endothelial dysfunction that defines thrombogenicity, inflammatory changes, vascular reactivity and the stability of atherosclerotic plaques is directly related to the progression of coronary artery disease and also NAFLD [4]. In NAFLD the endothelial cells of hepatic sinusoid are damaged, the production of cytokines, free radicals and collagen increases, and as a result - the change of sinusoid fenestration, collagenization of Disse's space and growth of intrahepatic vascular resistance, which, in its turn, provokes significant hepatic circulation disorders, ischemia development, liver tissue necrosis accompanied by fibrosis of these sites in the liver [5].

Today one of the endothelial dysfunction markers, directly related to both $\mathrm{CHD}$ and NAFLD is asymmetric dimethylarginine (ADMA). Intracellular production of ADMA happens through the arginine demethylation by the class of enzymes known as arginine-N-methyltransferase and further proteolysis releases ADMA [6]. ADMA is an endogenous inhibitor of NO-synthase enzyme that catalyzes the conversion of L-arginine into nitric oxide (NO) - a powerful vasodilative agent. ADMA plasma levels are related to its release in the process of protein breakdown and its splitting into dymetylamyn and citrulline under the influence of enzyme dimethylarginine dimethylaminohydrolase (DDAH). DDAH is present in the liver, pancreas, spleen and kidneys, but the liver DDAH plays a dominant role in the utilization of plasma ADMA [7].

Recently the significance of ADMA as a new risk factor for CVD was defined. In The Ludwigshafen Risk and Cardiovascular Health Study - a significant prospective study with an average observation period of 5.5 years it was estimated that the concentration of ADMA plasma levels is associated with mortality from cardiovascular and other causes in patients with stable and unstable angina regardless of known risk factors. [8]. In another study with an observation period of 24 years, Leong et al. (2008) showed the relation between the increased blood ADMA levels and the increase of the frequency of myocardial infarction and stroke in women [9]. Also, the relationship between the content of ADMA and severity of coronary artery disease, the influence of ADMA concentration on prognosis and survival of patients with cardiovascular system disorders was found out [10].

Besides the prevention of the NO synthesis through the competitive braking of eNOS, ADMA may promote further breaking of its enzymatic activity and transformation into the generator of superoxide. It is believed that this ADMA activity contributes further endothelial dysfunction and may play a significant role in the pathogenesis of liver diseases, acting as a source of vessels oxidative stress [11].

However, data on the particularities of concentration changes in ADMA serum level as a marker of endothelial dysfunction, depending on the functional state of the liver in patients with coronary artery disease and concomitant NAFLD are limited; the relationship of ADMA with components of the metabolic syndrome in these patients has not yet been investigated. Thus, the role of endothelial dysfunction in the pathogenesis of CHD comorbid with NAFLD requires further study.

The objective of the research: to study changes in the vascular endothelium state in interconnection with clinical and metabolic features in CHD patients with the concomitant nonalcoholic fatty liver disease.
Патология. - 2017. T. 14, № 1(39). C. 62-67 


\section{Materials and methods of the research}

Cross-cohort analytical study in parallel groups involved 86 patients, the primary group consisted of 34 patients with documented coronary artery disease, stable II-III functional class (FC) exertional angina combined with NAFLD, median age 60 ( $57.5 ; 66)$; comparison group: 32 patients with IBS without NAFLD, median age $60.5(51.5 ; 65.6)$. The control group consisted of 20 healthy individuals, the median age 58 (54; 60). Groups are comparable in age, sex, comorbidities nature, duration of $\mathrm{CHD}$. Before being included in the study, all participants provided written consent. II and II FC exertional angina were diagnosed under the classification of the Canadian Heart Association. The nonalcoholic fatty liver disease was determined by ultrasound examination of the liver according to the generally accepted methodology.

Criteria of including into the study: informed consent of the patient, the presence of verified CHD and NAFLD. The excluding criteria: patient with alcoholic liver disease or cirrhosis, autoimmune and viral hepatitis; autoimmune disorders; acute coronary syndrome or acute cerebrovascular accident in less than 3 months prior to the study; decompensated heart failure; oncological diseases.

All the patients with coronary artery disease were subjected to a comprehensive examination under the generally accepted standards ( $\mathrm{MOH}$ of Ukraine number 436 of 03.07.2006). Anthropometric measurements included the definition of height, weight, body mass index. The study of total cholesterol (W), triglycerides (TG), high-density lipoproteins (HDL), low-density lipoprotein (LDL), blood glucose, the activity of alanine aminotransferase (ALT), aspartate aminotransferase (AST), alkaline phosphatase (ALP), gamma-glutamyltransferase (GGT), thymol test performance, total bilirubin concentration was performed by standard biochemical techniques. To assess the degree of insulin resistance indexes HOMA-IR and CARO were used.

The thickness of intima-media vascular endothelial complex was measured in all the patients on the eSaote Mylab40 (Italy) apparatus. The research of the main head and neck arteries on the right and left front of the neck with the patient in supine position was conducted through the ultrasonic scanning with the linear transducer in B-mode at frequencies from 7 to $13 \mathrm{MHz}$. The common carotid arteries, ICA were scanned. The examination was carried out with the patient supine with his head turned $45^{\circ}$ in the direction opposite to the artery studied. During each examination, the intima-media thickness (IMT) of the carotid artery was determined. The arithmetic mean of the three indicators was taken into account. IMT less than $0.9 \mathrm{~mm}$ was considered as normal, 0.9-1.4 mm was regarded as thickening, and more than $1.4 \mathrm{~mm}$ - as the formation of atherosclerotic plaque.

Using a standard set of reagents ELISA the level of asymmetric dimethylarginine (Immundiagnostik), insulin (Monobind, USA) and CRP (Biomerica) was determined.

Statistical data processing was carried out by using the software package Statistica 10.0 (StatSoft Inc., № AXXR712D833214FAN5). Analysis of the nature of the distribution of variables was assessed under the Kolmogorov-Smirnov's criterion (D). Since all the analyzed data differed from the normal distribution, we used Mann-Whitney U-criterion to compare indexes from two independent samples. The comparison of quality indicators was performed using the $x^{2}$ criterion. To assess the type of communication and forecast values of variables we used the regression analysis and the analysis of operating characteristics curves (ROC - Receiver Operating Characteristic curve analysis), with the calculation of the area under the ROC-curve (AUC - Area under the ROC curve) and its $95 \%$ confidence interval. The AUC value more than 0.5 was defined as statistically significant. The assessment of the interrelationship between pairs of independent indexes, expressed in quantitative scale, was carried out due to the Spearman rank correlation coefficient $(r)$. All data are presented as median and distribution quartiles, Me (Q25; Q75). Differences were considered significant at $p<0.05$.

\section{Results and their discussion}

Due to the analyses of the main clinical characteristics it was found out that in patients with coronary artery disease and NAFLD the reliably higher rates of BMI, waist circumference, SBP were observed in comparison with those in the group of healthy persons and IHD patients without concomitant NAFLD $(p<0.05)$ (Table 1).

In patients with coronary artery disease and NAFLD a reliable increase in the value of BMI by $22.25 \%$ was marked if to be compared with the control group and by $13 \%$ if compared with patients with coronary artery disease $(p<0.05)$. The trend to the increase in levels of total cholesterol and LDL cholesterol, atherogenic index and to the reduction of $\mathrm{HDL}$ cholesterol in the intervention

Table 1. Clinical and laboratory characteristics of patients with coronary artery disease depending on the presence of concomitant NAFLD

\begin{tabular}{llll}
\hline $\begin{array}{l}\text { Index, } \\
\text { Unit (of measurement) }\end{array}$ & $\begin{array}{l}\text { Control group } \\
(\mathbf{n = 2 0})\end{array}$ & $\begin{array}{l}\text { CHD } \\
(\mathbf{n = 3 2})\end{array}$ & $\begin{array}{l}\text { CHD and NAFLD } \\
\text { (n=34) }\end{array}$ \\
\hline $\mathrm{BMl}, \mathrm{kg} / \mathrm{m}^{2}$ & $26.29(24.08 ; 29.26)$ & $28.73(27.7 ; 31.88)$ & $32.44(29.13 ; 37.62)^{\# *}$ \\
Waist, sm & $80.66(73.94 ; 96.42)$ & $89.13(79.3 ; 101.6)$ & $94.82(88.5 ; 105.1)^{\# *}$ \\
Systolic BP, $\mathrm{mmHg}$ & $125.0(110.0 ; 130.0)$ & $140.0(130.0 ; 145.0)$ & $160.0(160.0 ; 170.0)^{\# *}$ \\
Diastolic BP, mmHg & $80.0(70.0 ; 90.0)$ & $80.0(65.0 ; 90.0)$ & $95.0(90.0 ; 100.0)$ \\
General cholesterol, mmol/l & $4.84(4.57 ; 6.32)$ & $5.01(4.21 ; 5.55)$ & $5.67(4.24 ; 6.29)$ \\
LDL, mmol/l & $2.86(2.14 ; 4.29)$ & $3.91(3.35 ; 4.1)$ & $3.20(2.79 ; 3.57)$ \\
HDL, mmol/l & $1.2(1.12 ; 1.48)$ & $1.11(0.75 ; 1.37)$ & $0.96(0.86 ; 1.34)$ \\
TG, mmol/l & $1.06(1.05 ; 1.13)$ & $1.66(0.8 ; 1.95)$ & $2.27(1.28 ; 2.75)^{\# *}$ \\
Atherogenicity index & $2.45(2.05 ; 3.19)$ & $3.03(2.13 ; 3.76)$ & $3.63(3.42 ; 3.81)$ \\
\hline
\end{tabular}

*: the probability of indexes difference if compared with the control selected group $(p<0.05)$;

$\#$ : the probability of indexes difference if compared with the patients with coronary artery disease $(p<0.05)$. 
group was observed in comparison with patients with $\mathrm{CHD}$ and practically healthy persons. Triglyceride levels in patients with coronary artery disease and NAFLD were significantly 2 times higher than in the control group and by $36 \%$ - compared with patients without liver disease $(\mathrm{p}<0.05)$.

In analyzing the parameters of carbohydrate metabolism and insulin resistance (Table 2) the following changes were revealed: by the level of glucose the significant difference between groups was not found; in patients with coronary heart disease associated with NAFLD, there was a significant $(p<0.05)$ increase in insulin levels as compared to healthy persons (4.75 times) and CHD patients without structural and functional changes in the liver (2.42 times). A similar tendency was observed in terms of HOMA index. Its 5 times increase in comparison with healthy people was revealed, 2.35 times increase in patients with ischemic heart disease, respectively $(p<0.05)$. CARO index was 3.43 times lower in patients with a core group compared with healthy people and 2 times lower compared with patients without comorbid coronary artery disease pathology $(p<0.05)$. Revealed violations indicate the development of insulin resistance which is associated with an imbalance of adipocytokines level, typical for this category of patients [12].

Features of the liver functional state in patients with coronary artery disease depending on the presence of concomitant NAFLD are shown in Table 3.

In patients with coronary heart disease associated with NAFLD, there was a significant $(p<0.05) 3.18$ times increase in levels of alkaline phosphatase compared to the control group and 1.35 times increase in comparison with patients with IBS without liver pathology. Serum GGT in patients with coronary artery disease with NAFLD was 2 times higher compared with healthy individuals $(p<0.05)$ but did not differ significantly from the similar characteristic of the compared group. According to other parameters of the liver functional state, significant differences between groups were not found due to the prevalence of patients with steatosis than with steatohepatitis $(79.5 \%$ vs. $20.5 \%)$ in the study group.

Indicators of endothelial dysfunction in patients with coronary artery disease depending on the availability of NAFLD are presented in Table 4.

It was found out that in patients with coronary artery disease NAFLD, the ADMA serum level was $42 \%$ higher than in healthy individuals and $21 \%$ higher compared with the group of CHD patients without liver disease $(p<0.05)$; according to the level of CRP the study group patients 5.16 times dominated the control group and 1.63 times the comparison group $(p<0.05)$. The thickness of intima-media significantly prevailed in patients with comorbid disorders: $1.15(1.00 ; 1.2)$ against $0.94(0.9 ; 1.0) \mathrm{mm}$ in patients with CHD and $1.15(1.00 ; 1.2)$ against $0.78(0.7 ; 0.8) \mathrm{mm}$ in healthy individuals $(p<0.05)$. The frequency of registration of intima-media thickening in patients with concomitant coronary artery disease and NAFLD and in the comparison group are shown in Fig. 1.

Table 2. Carbohydrate metabolism and insulin resistance characteristics in patients with coronary artery disease depending on the presence of concomitant NAFLD

\begin{tabular}{|c|c|c|c|}
\hline $\begin{array}{l}\text { Index, } \\
\text { Unit (of measurement) }\end{array}$ & $\begin{array}{l}\text { Control group } \\
(n=20)\end{array}$ & $\begin{array}{l}\text { CHD } \\
(n=32)\end{array}$ & $\begin{array}{l}\text { CHD and NAFLD } \\
(n=34)\end{array}$ \\
\hline Glucose, $\mathrm{mmol} / \mathrm{l}$ & $4.20(4.1 ; 4.72)$ & $4.35(3.90 ; 4.90)$ & $5.00(4.10 ; 5.80)$ \\
\hline Insulin, mkOd/ml & $3.57(3.43 ; 5.33)$ & $7.41(0.57 ; 13.50)$ & $17.00(6.33 ; 22.77)^{\# \star}$ \\
\hline HOMA-IP & $0.66(0.62 ; 0.99)$ & $1.43(0.68 ; 1.73)$ & $3.37(1.50 ; 5.80)^{\# \star}$ \\
\hline Index CARO & $1.03(0.83 ; 1.19)$ & $0.61(0.38 ; 0.76)$ & $0.30(0.22 ; 0.88)^{\# \star}$ \\
\hline
\end{tabular}

*: the probability of indexes difference if compared with the control selected group $(p<0.05)$;

$\#$ : the probability of indexes difference if compared with the patients with coronary artery disease $(p<0.05)$.

Table 3. Characteristics of the liver functional state in patients with coronary artery disease depending on the presence of concomitant NAFLD

\begin{tabular}{llll}
\hline $\begin{array}{l}\text { Index, } \\
\text { Unit (of measurement) }\end{array}$ & $\begin{array}{l}\text { Control group } \\
(\mathbf{n}=\mathbf{2 0})\end{array}$ & $\begin{array}{l}\text { CHD } \\
(\mathbf{n}=32)\end{array}$ & $\begin{array}{l}\text { CHD and NAFLD } \\
(\mathbf{n}=34)\end{array}$ \\
\hline ALT, umol/ml×h & $0.55(0.34 ; 0.68)$ & $0.61(0.51 ; 0.79)$ & $0.73(0.44 ; 0.82)$ \\
AST, umol/m|xh & $0.45(0.26 ; 0.63)$ & $0.44(0.38 ; 0.58)$ & $0.49(0.33 ; 0.72)$ \\
Bilirubin, umol/l & $8.0(3.2 ; 11.7)$ & $14.35(10.0 ; 17.3)$ & $14.45(8.75 ; 18.0)$ \\
Thymol test, un. & $1.86(0.76 ; 3.43)$ & $3.02(2.0 ; 3.86)$ & $2.33(1.61 ; 3.0)$ \\
Alkaline phosphatase, nmol/(s*l) & $1185.71(1016.32 ; 1278.10)$ & $2802.59(2602.41 ; 2894.99)$ & $3772.72(3572.54 ; 4850.64)^{\# *}$ \\
Gamma glutamyl transferase, un/l & $5.68(2.72 ; 10.14)$ & $8.9(4.45 ; 11.1)^{*}$ & $11.62(6.68 ; 26.7)^{*}$ \\
\hline
\end{tabular}

*: the probability of indexes difference if compared with the control selected group $(p<0.05)$;

$\#$ : the probability of indexes difference if compared with the patients with coronary artery disease $(p<0.05)$.

Table 4. Indicators of endothelial dysfunction in patients with coronary artery disease depending on the availability of NAFLD

\begin{tabular}{llll}
\hline $\begin{array}{l}\text { Index, } \\
\text { Unit (of measurement) }\end{array}$ & $\begin{array}{l}\text { Control group } \\
(\mathbf{n = 2 0})\end{array}$ & $\begin{array}{l}\text { CHD } \\
(\mathbf{n = 3 2})\end{array}$ & $\begin{array}{l}\text { CHD and NAFLD } \\
(\mathbf{n = 3 4 )}\end{array}$ \\
\hline CRP, mg/l & $0.6(0.4 ; 0.8)$ & $1.9(1.5 ; 2.5)$ & $3.1(3.1 ; 4.3)^{\# \star}$ \\
ADMA, umol/l & $0.5(0.44 ; 0.53)$ & $0.71(0.63 ; 0.76)$ & $0.86(0.84 ; 0.96)^{\# \star}$ \\
IMT, mm & $0.78(0.7 ; 0.8)$ & $0.94(0.9 ; 1.0)$ & $1.15(1.00 ; 1.2)^{\# \star}$ \\
\hline
\end{tabular}

*: the probability of indexes difference if compared with the control selected group $(p<0.05)$;

$\#$ : the probability of indexes difference if compared with the patients with coronary artery disease $(p<0.05)$. 


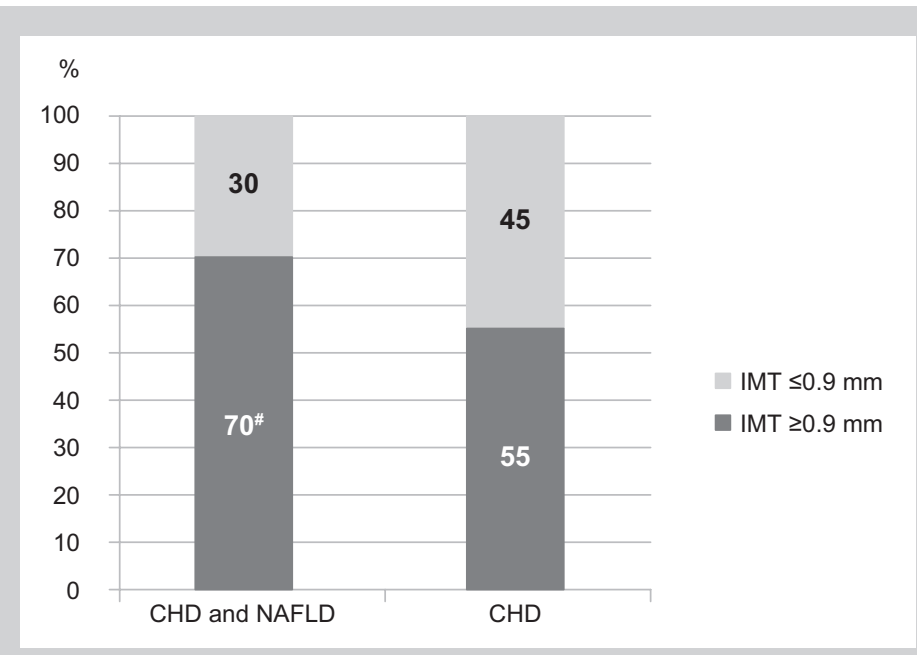

Fig. 1. The frequency of registration of intima-media thickening in patients with concomitant coronary artery disease and NAFLD and in the comparison group.

\#: the probability of indicators difference if compared with patients with coronary artery disease, according to the $x^{2}$ criterion, $(p<0.05)$

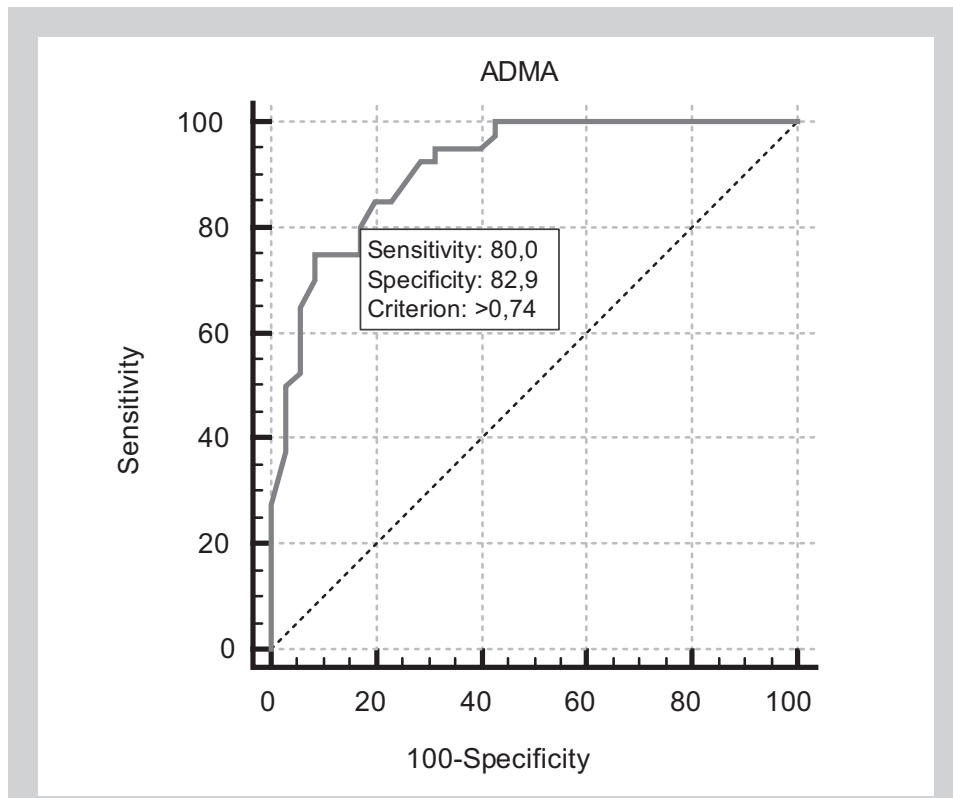

Fig. 2. The results of ROC-analysis of the ADMA serum levels relationship with intima-media complex thickness in patients with coronary artery disease combined with nonalcoholic fatty liver disease.

The analysis of the frequency of registration of the intima-media thickening showed that among patients of the main group there were $15 \%$ more individuals with the index IMT $\geq 0.9 \mathrm{~mm}\left(X^{2}=4.89 ; p<0.05\right)$.

To assess the effectiveness of determining the ADMA serum levels as a marker of structural and functional changes in blood vessels in ischemic heart disease, comorbid with NAFLD the ROC-analysis was conducted. The defining of the presence of the intima-media complex thickening was used as a reference method. The ROC-curve area was built, the area under which was equal to $A \cup C=0.91$ subject to a $5 \%$ confidence interval: 0.825 to 0.966 .

It was determined that the level of ADMA $>0.74 \mathrm{mmol} /$, is the cutting point and has an optimal ratio of sensitivity
$(80 \%)$ to specificity ( $82.9 \%)$ considering the diagnostics of vascular remodeling. This statistically justified threshold value is the highly reliable factor associated with structural and functional changes in vascular endothelium in patients with coronary artery disease combined with NAFLD. The area under the ROC-curve of more than 0.8 indicates a statistically reliable threshold value with high quality of chosen model.

The presence of correlation relationship of ADMA concentrations with CRP levels $(r=+0.56$; $p<0.05)$, testifying the role of immunoinflammatory changes in the development of endothelial dysfunction in patients with coronary artery disease concomitant with NAFLD was defined. The results obtained coincide with the modern research confirming the role of systemic inflammation as a leading pathophysiological mechanism in the nonalcoholic fatty liver disease, which contributes to the development of endothelial dysfunction and, consequently, to the progression of coronary artery disease [13].

In patients with coronary artery disease and NAFLD the reliable direct relationship of ADMA rate with classic risk factors for cardiovascular disease was revealed: total cholesterol $(r=+0.47 ; p<0.05)$, BMl $(r=+0.53 ; p<0.05)$, glucose $(r=+0.65 ; p<0.05)$, and the significant negative relationship of ADMA with $\mathrm{HDL}(r=-0.48 ; p<0.05)$; IMT with BMI $(r=+0.56 ; p<0.05)$, glucose $(r=+0.43 ; p<0.05)$, the level of SBP $(r=+0.46 ; p<0.05)$, thus specifying the association of endothelial dysfunction with the development and progression of metabolic disorders in this comorbid conditions. The relationship of ED with metabolic disorders was found in the works of other scholars. It is proved that carbohydrate metabolism disorders, IR and obesity are important factors of ED and early vascular aging (EVA-Syndrome) $[14,15]$. According to N. M. Hromnatska (2014), the development of ED and increase in arterial stiffness is a versatile reaction of tissue to IR and inflammatory stress, inherent both to CHD and NAFLD [16].

The presence of relationships between the ADMA endothelial dysfunction marker and liver damage principal indicators in patients with coronary artery disease, combined with NAFLD was established: ALT $(r=+0.71$; $p<0.05)$, ALT $(r=+0.76 ; p<0.05)$; IMT levels of GGT $(r=+0.55 ; p<0.05)$, which goes with the literature. Thus, A. P. Schekotova (2013) in her study traced the authentic relationship of endothelial damage markers and indicators of the cholestatic syndrome. The authors, however, suggest that endothelial damage at the same time depends not so much on the functional state of the liver and hepatocytes defeat as on the impact of hostility factors (inflammation, viral agents) directly on the endothelium [17]. However, according to other authors (O. B. Dynnyk, L. A. Stadnyuk, 2008), it was estimated that generally accepted indicators of endothelial dysfunction (vasodilation endothelium, circulating endothelial cells) progressively worsen with the increasing severity of liver disease and are associated with changes in its functional state [18].

\section{Conclusions}

1. In patients with coronary artery disease, combined with NAFLD, an increase in serum levels of asymmetric 
dimethylarginine, CRP, and thickening of intima-media segment compared with patients with $\mathrm{CHD}$ without concomitant liver disease are observed, thus indicating the presence of endothelial dysfunction in the background of activation of systemic inflammation in these patients.

2. The level of $A D M A>0.74 \mathrm{mmol} / \mathrm{l}$ with sensitivity $(80 \%)$ and specificity ( $83 \%$ ) allows diagnosing structural and functional changes in vascular endothelium in patients with coronary artery disease combined with NAFLD, thus indicating that its value is a marker of vascular remodeling in these patients.

3. Markers of structural and functional state of endothelium in patients with coronary artery disease and NAFLD are associated with the metabolic disorders (BMI, waist volume, SBP, levels of glucose, cholesterol, insulin resistance) and indicators of liver disease (ALT, alkaline phosphatase, GGT) indicating the generality of pathogenetic mechanisms of the development and progression of these comorbid disorders.

Prospects for further research: identification of opportunities for pharmacological correction of endothelial dysfunction and metabolic disorders found in patients with $\mathrm{CHD}$ associated with nonalcoholic fatty liver disease is a promising direction for our further research.

\section{References}

[1] Syvolap, V. D., \& Mykhailovska, N. S. (2011). Prohnozuvannia fatalnykh i nefatalnykh koronarnykh podii u khvorykh na Q-infarkt miokarda z metabolichnym syndromom [Prediction of fatal and non-fatal coronary events in patients with Q-myocardial infarction and metabolic syndrome]. Zaporozhye medical journal, 1, 26-29. [in Ukrainian].

[2] Skybchuk, V. A., \& Onyschuk, Yu. I. (2014). Nealkoholna zhyrova khvoroba pechinky: suchasni pidkhody do diahnostyky ta likuvannia [Nonalcoholic fatty liver disease: current approaches to diagnosis and treatment]. Mystetstvo likuvannia, 2, 6-9. [in Ukrainian].

[3] Alam, S., Mustafa, G., Alam, M., \& Ahmad, N. (2016). Insulin resistance in development and progression of the nonalcoholic fatty liver disease. World Journal of Gastrointestinal Pathophysiology, 7(2), 211. doi: 10.4291/wjgp.v7.i2.211.

[4] Mykhailovska, N. S., Oliinyk, T. V., \& Mykhailovskyi, Y. M. (2015) Kliniko-patohenetychna rol imunozapalnykh porushen ta endotelialnoi dysfunktsii u khvorykh na ishemichnu khvorobu sertsia, komorbidnu z hipotyreozom [Clinical and pathogenetic role of immunoinflammatory disorders and endothelial dysfunction in patients with ischemic heart disease comorbid with hypothyroidism (reference review).]. Bukovynskyi medychnyi visnyk, 1(73), 227-231. [in Ukrainian].

[5] Pivtorak, K. V. (2015). Dysfunktsiia endoteliiu ta porushennia funktsii pechinky pry nealkoholnii zhyrovii khvorobi pechinky [Endot helial dysfunction and violations of liver funct ion in nonalcoholic fatt y liver disease]. Visnyk Vinnytskoho natsionalnoho medychnoho universytetu, 2, 545-549. [in Ukrainian].

[6] Sibal, L., Agarwal, S. C., Home, P. D., \& Boger, R. H. (2010). The Role of Asymmetric Dimethylarginine (ADMA) in Endothelial Dysfunction and Cardiovascular Disease. Current Cardiology Reviews, 6(2):82-90. doi: 10.2174/157340310791162659.

[7] Ferrigno, A., Pasqua, L. G Di., Berardo, C., Richelmi, P., \& Vairetti, M. (2015). The liver plays a central role in asymmetric dimethylarginine-mediated organ injury. World Journal of Gastroenterology, 21(17), 5131-5137. doi: 10.3748/wjg.v21.i17.5131.

[8] Meinitzer, A., Seelhorst, U., Wellnitz, B., Halwachs-Baumann, G., Boehm, B., Winkelmann, B., \& Marz, W. (2007). Asymmetrical Dimethylarginine Independently Predicts Total and Cardiovascular Mortality in Individuals with Angiographic Coronary Artery Disease (The Ludwigshafen Risk and Cardiovascular Health Study). Clinical Chemistry, 53(2), 273-283. doi: 10.1373/clinchem.2006.076711.

[9] Leong, T., Zylberstein, D., Graham, I., Lissner, L., Ward, D., Fogarty, J., Bengtsson, C., et al. (2008). Asymmetric Dimethylarginine Independently Predicts Fatal and Nonfatal Myocardial Infarction and Stroke in Women: 24-Year Follow-Up of the Population Study of Women in Gothenburg. Arteriosclerosis, Thrombosis, and Vascular Biology, 28(5), 961-967. doi: 10.1161/ATVBAHA.107.156596.
[10] Schulze, F., Lenzen, H., Hanefeld, C., Bartling, A., Osterziel, K., Goudeva, L., et al. (2006). Asymmetric dimethylarginine is an independent risk factor for coronary heart disease: Results from the multicenter Coronary Artery Risk Determination investigating the Influence of ADMA Concentration (CARDIAC) study. American Heart Journal, 152(3), 493.e1-493. e8. doi: 10.1016/j.ahj.2006.06.005.

[11] Vairappan, B. (2015). Endothelial dysfunction in cirrhosis: Role of inflammation and oxidative stress. World Journal of Hepatology, 7(3), 443. doi: 10.4254/wjh.v7.i3.443.

[12] Mykhailovska, N. S., \& Miniailenko, L. E. (2016). The peculiarities of adiponectin and resistin interrelationships with the components of metabolic syndrome in patients with coronary heart disease and concomitant nonalcoholic fatty liver disease. Zaporozhye medical journal, 5(98), 25-30. doi: 10.14739/2310-1210.2016.5.82568.

[13] Bueverov, A. O., \& Bogomolov, O. N. (2009). Nealkogol'naya zhyrovaya bolezn' pecheni: obosnovanie patogeneticheskoj terapii [Nonalcoholic fatty liver disease: a study of pathogenetic therapy]. Klinicheskie perspektivy gastrojenterologii, 1, 3-9. [in Russian].

[14] Hughes, T., Althouse, A., Niemczyk, N., Hawkins, M., Kuipers, A., \& Sutton-Tyrrell, K. (2012). Effects of weight loss and insulin reduction on arterial stiffness in the SAVE trial. Cardiovascular Diabetology, 11(1), 114. doi: 10.1186/1475-2840-11-114

[15] Dudinskaya, E. N., Tkacheva, O. N., Strazhesko, I. D., \& Akasheva, D. U. (2013). Rol' insulinorezistentnosti i eyo korrekcii v processakh sosudistogo stareniya [Role of insulin resistance and its correction in the process of vascular aging]. Rational Pharmacotherapy in Cardiology, 9(2), 163-170. doi: http://dx.doi.org/10.20996/1819-6446-2013-9-2163-170. [in Russian]

[16] Gromnatska, N. M., Sklyarov, Ye. Ya., \& Fomenko, I. S. (2014). Markery endotelialnoi dysfunktsii pry insulinorezystentnosti v ditei i pidlitkiv [Endothelial dysfunction markers in insulin resistance in children and adolescents]. Perinatologiya i pediatriya, 4, 72-76. [in Ukrainian]. doi10.15574/PP.2014.60.72

[17] Schekotova, A. P., Kotelnikova, L. P., Mugatarov, I. N., \& Fedachuk, N. N. (2013). E'ndotelial'naya disfunkciya, vospaleniye i fibroz pri gepatobilyarnoj patologii [Endothelial dysfunction, inflammation and fibrosis in the presence of hepatobiliary pathology]. Fundamental'nye issledovaniya, 5, 451-455. [in Russian]

[18] Dynnyk, O. B., Stadnyuk, L. A., Mostovyi, S. E., \& Myshanych, O. N. (2008). Pokaznyky dysfunktsii endoteliiu ta stan vnutrishnosertsevoi hemodynamiky u khvorykh z dyfuznymy zakhvoriuvanniamy pechinky [Indicators of the state of endothelial dysfunction and intracardiac hemodynamics in patients with the diffuse liver disease]. Ukrainskyi kardiolohichnyi zhurnal, 6, 66-74. [in Ukrainian].

\section{Information about authors:}

Mykhailovska N. S., MD, PhD, DSc, Professor,

Head of the Department of General Practice - Family Medicine,

Zaporizhzhia State Medical University, Ukraine.

Miniailenko L. Ye., PhD Student at the Department of General

Practice - Family Medicine, Zaporizhzhia State Medical University, Ukraine.

\section{Відомості про авторів:}

Михайловська Н. С., А-р меА. наук, професор, зав. каф. загальної практики - сімейної медицини, Запорізький державний медичний університет, Україна.

Міняйленко ^. Є., аспірант каф. загальної практики - сімейної медицини, Запорізький державний медичний університет, Україна.

\section{Сведения об авторах:}

Михайловская Н. С., А-р меА. наук, профессор, зав. каф. общей практики - семейной меАицины, Запорожский государственный медицинский университет, Украина.

Миняйленко ^. Е., аспирант каф. общей практики - семейной медицины, Запорожский государственный медицинский университет, Украина.

Конфлікт інтересів: віАсутній.

Conflicts of Interest: authors have no conflict of interest to declare.

Надійшло Ао редакції / Received: 21.02.2017

Після Аоопрацювання / Revised: 28.02.2017

Прийнято Ао Аруку / Accepted: 01.03.2017 